\title{
The effect of mycorrhizal inoculation and liquid organic fertilizer on growth and yield of red chili
}

\author{
Anditya Gilang Rizky Pradana ${ }^{1}$ Puji Harsono ${ }^{2 *}$, and Amalia Tetrani Sakya ${ }^{2}$ \\ ${ }^{1}$ Master Program of Agronomy, Faculty of Agriculture, Sebelas Maret University, 57126 Surakarta, \\ Indonesia \\ ${ }^{2}$ Department of Agrotechnology, Faculty of Agriculture, Sebelas Maret University, 57126 Surakarta, \\ Indonesia
}

\begin{abstract}
Red chili is one of the strategic horticultural commodities in Indonesia. Improved cultivation technology is required to increase the production of red chili. This research aim to determines the optimal dosage of arbuscular mycorrhizal fungi (AMF) and the concentration of liquid organic fertilizer (LOF) to increase the growth and yield of red chili. The research was designed in a Factorial Randomized Complete Block. The first factor was mycorrhizae with three dosages levels: 0,5 , and $10 \mathrm{~g} \mathrm{plant}^{-}$ ${ }^{1}$. The other factor was liquid organic fertilizer with 4 level concentrations of $0,5,10$, and $15 \mathrm{ml} \mathrm{l}^{-1}$. The result shows that mycorrhizal inoculation increase the root absorption area. Liquid organic fertilizer increased nutrient sources for plants and improved the physical, biological, and chemical soil. Mycorrhizal inoculation and LOF improved the growth of red chili, there were plant height, number of branches, stem diameter, header width, and leaf area index. The yield components also increased the number of fruit, fruit length, fruit weight, and productivity. The highest productivity was resulted by the treatment of AMF $10 \mathrm{~g} \mathrm{plant}^{-1}$ and $15 \mathrm{ml} \mathrm{l}^{-}$ ${ }^{1} \mathrm{LOF}\left(11.16 \mathrm{t} \mathrm{ha}^{-1}\right)$, that was $33 \%$ higher than without treatment.
\end{abstract}

\section{Introduction}

Red chili is a horticultural commodity that has economic value in Indonesia. Red chilies can grow both in the lowlands and highlands according to environmental conditions. In unfavorable environmental conditions, red chilies make adaptations to survive. Red chili can increase income, as a source of vitamin $\mathrm{C}$ and be used as medicine and cosmetics because of the capsaicin content [1]. National red chili production in 2019 reached 1.2 million tons with a harvest area of 133,436 ha which decreased by $3.02 \%$ from 2018 [2].

Currently, there are constraints experienced by farmers in the chili cultivation process. The problems are pests and diseases such as fusarium wilt, anthracnose, gemini virus, and rotten fruit, which cause crop failure. In addition, low fruit productivity and long harvest times will reduce the profits of farmers. Consumption of red chili is increase but production has decreased. The high demand for chili consumption must be fulfilled by increasing

\footnotetext{
* Corresponding author: pharsono61@gmail.com
} 
production through an intensification program. The components include soil quality improvement and fertilization.

Applying organic fertilizers reduces environmental pollution, increases production, and sustainably improves the land quality [3]. The advantage of LOF is increasing nutrient absorption effectiveness, easier to absorb, improves the quality of plant products, and reduces inorganic fertilizer [4]. The application of liquid organic fertilizers can also increase the growth and yield of red chili [5].

Soil quality degradation damages biological, physical, and chemical soil. This damage interferes with the performance of beneficial microorganisms, which increases to absorb nutrients. One of the technologies that can improve soil quality and be environmentally friendly is arbuscular mycorrhizal fungi (AMF). AMF is a microorganism that can be used as biological fertilizer to help supply nutrients through root colonization [6]. The inoculation of AMF can increase the absorption zone, increase the availability of nutrients, and absorb $\mathrm{P}$ elements to water availability so that plants are resistant to water stress and pest attacks [7].

According to Sanchez-roque and Perez [8], giving AMF causes a symbiosis between AMF and chili so that the effects occur morphological and physiological changes, increase nutrition for plants and increase the wet weight of roots and fruit. AMF can interact synergistically with beneficial microorganisms populations, for example in phosphate solubilizing bacteria [9]. The research Purnomo [10] said that Gigaspora margarita inoculation could increase the fruit weight of the harvest in Cilibangi 3 chili and Helm chili. The aim of this study was to investigate the effect of mycorrhizal inoculation and liquid organic fertilizers application on growth and yield of red chili.

\section{Materials and methods}

The material used in this study consisted of red chili varieties TM 999 F1, Mycogrow mycorrhizal biological fertilizers (Glomus manihotis, Glomus infraradices, Glomus aggregatum, Acaulospora sp. and Gigaspora sp.), Pomi liquid organic fertilizer (N 5.09\%, $\mathrm{P}_{2} \mathrm{O}_{5} 4.3 \%, \mathrm{~K}_{2} \mathrm{O}_{5}$ 5.45\%, Azoprillium sp. 8,0 x $10^{8}$ CFU/gr, Acetobacter sp. $9.6 \times 10^{8}$ CFU/gr, Pseudomonas sp. $5.9 \times 10^{8} \mathrm{CFU} / \mathrm{gr}$, Bacillus sp. $2.8 \times 10^{8} \mathrm{CFU} / \mathrm{gr}, \mathrm{Fe} 410 \mathrm{ppm}$, Mn 737 ppm, Cu 440 ppm, Zn 354 ppm, B 260 ppm, Co 12 ppm, Mo 3 ppm, C organic 28.53\%), 16-16-16 NPK fertilizer, $20 \mathrm{t} \mathrm{ha}^{-1}$ manure, and mulch.

The research was designed in a Factorial Randomized Complete Block with two factors. The first factor was arbuscular mycorrhiza fungi (AMF), consisting of 3 levels: the application dose of 0,5 , and 10 gr plant $^{-1}$. The other factor was liquid organic fertilizer (LOF), consisting of 4 levels, namely concentrations of $0,5,10$, and $15 \mathrm{ml} \mathrm{l}^{-1}$. In the experiment, there were three blocks and had 36 experimental units.

Implementation of research in the field starting from the nursery, land cultivation, rearing, and harvesting. Observations of growth parameters include plant height, number of branches, leaf area index, header width, and stem diameter. The yield parameters were fruit length, fruit diameter, number of fruits per plant, total fruit per plant weight, and productivity. The data from the observations were analyzed using the ANOVA test, and the DMRT test was carried out at the $\alpha 5 \%$ level. Data analysis using SAS 9.0. and R Studio Software.

\section{Results and discussion}

The combination treatment between mycorrhizal inoculation and LOF can increase the growth and yield of red chilies. LOF contains important microorganisms that will increase 
soil fertility in physics, biology, and chemistry to optimize plant growth and development [11]. AMF can increase nutrient uptake by expanding the surface area because external hyphae are smaller than the roots [12].

The interaction of the two treatments had a significant response on growth parameters, namely, stem diameter, plant height, number of branches, header width, and leaf area index (Table 1). The interaction between the two treatments also significantly affected yield parameters, the number of fruits, fruit diameter, fruit length, and productivity (Table 2).

\subsection{Red chili growth}

Mycorrhizal treatment $10 \mathrm{~g}$ plant $^{-1}+15 \mathrm{ml} \mathrm{l}^{-1}$ LOF produced the largest plant height is 124 $\mathrm{cm}$, while the smallest plant height is $90 \mathrm{~cm}$. The highest stem diameter in treatment $10 \mathrm{~g}$ plant $^{-1}+15 \mathrm{ml} \mathrm{l}^{-1}$ was $1.34 \mathrm{~cm}$. There is a significant difference between mycorrhizal treatments and liquid organic fertilizers based on the Duncan test. The availability of Nitrogen in liquid organic fertilizers can increase the vegetative growth of plants. According to Marliana [13] and Salisbury and Ross [14], Nitrogen is closely related to the synthesis of chlorophyll and protein and the development of meristem tissue that helps plant growth, such as plant height, stems, branches, and roots.

Table 1. The average of growth variables in red chili

\begin{tabular}{|c|c|c|c|c|c|}
\hline Treatments & $\begin{array}{l}\text { Plant } \\
\text { height } \\
\text { (cm) }\end{array}$ & $\begin{array}{c}\text { Stem } \\
\text { diameter } \\
\text { (cm) }\end{array}$ & $\begin{array}{c}\text { Number } \\
\text { of } \\
\text { brunches }\end{array}$ & $\begin{array}{c}\text { Header } \\
\text { width } \\
\text { (cm) }\end{array}$ & $\begin{array}{c}\text { Leaf } \\
\text { area } \\
\text { index }\end{array}$ \\
\hline 0 g plant $^{-1}+0 \mathrm{ml} \mathrm{l}^{-1}$ & $90 \mathrm{e}$ & $0.92 \mathrm{~g}$ & $90 \mathrm{~d}$ & $61.80 \mathrm{fg}$ & $1.02 \mathrm{~cd}$ \\
\hline $0 \mathrm{~g}_{\text {plant }}{ }^{-1}+5 \mathrm{ml} \mathrm{l}^{-1}$ & $93 \mathrm{e}$ & $0.94 \mathrm{~g}$ & $93 \mathrm{~cd}$ & $60.60 \mathrm{~g}$ & $1.05 \mathrm{~cd}$ \\
\hline 0 g plant $^{-1}+10 \mathrm{ml} \mathrm{l}^{-1}$ & $95 \mathrm{de}$ & $1.03 \mathrm{f}$ & $96 \mathrm{~cd}$ & $63.20 \mathrm{efg}$ & $0.99 \mathrm{~d}$ \\
\hline $0 \mathrm{~g} \mathrm{plant}^{-1}+15 \mathrm{ml} \mathrm{l}^{-1}$ & $103 \mathrm{bcd}$ & $1.05 \mathrm{ef}$ & $106 \mathrm{bcd}$ & $65.73 \mathrm{def}$ & $1.14 \mathrm{bc}$ \\
\hline $5 \mathrm{~g} \mathrm{plant}^{-1}+0 \mathrm{ml} \mathrm{l}^{-1}$ & 96 cde & $1.03 \mathrm{ef}$ & $100 \mathrm{bcd}$ & $61.60 \mathrm{fg}$ & $1.08 \mathrm{~cd}$ \\
\hline $5 \mathrm{~g} \mathrm{plant}^{-1}+5 \mathrm{ml} \mathrm{l}^{-1}$ & $105 \mathrm{bc}$ & $1.09 \mathrm{de}$ & $103 \mathrm{bcd}$ & $68.47 \mathrm{~cd}$ & $1.12 \mathrm{bc}$ \\
\hline $5 \mathrm{~g} \mathrm{plant}^{-1}+10 \mathrm{ml} \mathrm{l}^{-1}$ & $112 \mathrm{~b}$ & $1.12 \mathrm{~cd}$ & $119 a b$ & $66.97 \mathrm{de}$ & $1.26 \mathrm{a}$ \\
\hline 5 g plant $^{-1}+15 \mathrm{ml} \mathrm{l}^{-1}$ & 99 cde & $1.18 \mathrm{c}$ & $96 \mathrm{~cd}$ & $73.13 \mathrm{ab}$ & $1.31 \mathrm{a}$ \\
\hline $10 \mathrm{~g} \mathrm{plant}^{-1}+0 \mathrm{ml} \mathrm{l}^{-1}$ & $108 \mathrm{~b}$ & $1.05 \mathrm{ef}$ & $100 \mathrm{bcd}$ & $65.40 \mathrm{def}$ & $1.22 \mathrm{ab}$ \\
\hline $10 \mathrm{~g} \mathrm{plant}^{-1}+5 \mathrm{ml} \mathrm{l}^{-1}$ & $105 \mathrm{~b}$ & $1.18 \mathrm{c}$ & $109 \mathrm{bcd}$ & $72.13 \mathrm{bc}$ & $1.29 \mathrm{a}$ \\
\hline $10 \mathrm{~g} \mathrm{plant}^{-1}+10 \mathrm{ml} \mathrm{l}^{-1}$ & $107 \mathrm{~b}$ & $1.25 \mathrm{~b}$ & $112 \mathrm{abc}$ & $75.93 \mathrm{ab}$ & $1.32 \mathrm{a}$ \\
\hline $10 \mathrm{~g} \mathrm{plant}^{-1}+15 \mathrm{ml} \mathrm{l}^{-1}$ & $124 \mathrm{a}$ & $1.34 \mathrm{a}$ & $130 \mathrm{a}$ & $77.03 \mathrm{a}$ & $1.29 \mathrm{a}$ \\
\hline CV $(\%)$ & 4.54 & 3.17 & 9.90 & 3.53 & 5.45 \\
\hline F Value & $6.50 * *$ & $3.40 * *$ & $2.66^{*}$ & $3.33 *$ & $2.72 *$ \\
\hline
\end{tabular}

Note: The same letter in the same column is not significantly different based on the DMRT test $\alpha$ : $5 \%, *$ : significant, **: very significant effect, ns: no significant effect, CV: coefficient of variance.

The number of branches determines the number of chilies produced. The highest number of branches is $10 \mathrm{~g} \mathrm{plant}^{-1}+15 \mathrm{ml} \mathrm{l}^{-1}$ treatment, namely 130 branches, while the average was around 100 branches for other treatments. The largest crown width in treatment $10 \mathrm{~g} \mathrm{plant}^{-1}+15 \mathrm{~mL} \mathrm{~L}^{-1}$ is $77.03 \mathrm{~cm}$. The control treatment had a header width of $61.8 \mathrm{~cm}$ which was not significantly different from $5 \mathrm{~g} \mathrm{plant}^{-1}+0 \mathrm{ml} \mathrm{l}^{-1}$, namely $61.6 \mathrm{~cm}$.

The leaf area index character in red chilies is quite large based on table 1, treatment of 5 g plant ${ }^{-1}+10 \mathrm{ml} \mathrm{l}^{-1}, 5 \mathrm{~g} \mathrm{plant}^{-1}+15 \mathrm{ml} \mathrm{l}^{-1}, 10 \mathrm{~g} \mathrm{plant}^{-1}+5 \mathrm{ml} \mathrm{l}^{-1}, 10 \mathrm{~g}_{\text {plant }}^{-1}+10 \mathrm{ml} \mathrm{l}^{-1}$ and $10 \mathrm{~g} \mathrm{plant}^{-1}+15 \mathrm{ml} \mathrm{l}^{-1}$ were $1.26,1.31,1.29,1.32$ and 1.29 , which were not significantly different. The greater the leaf area value, the greater the photosynthate produced so that more photosynthate is translocated for plant growth and development [15]. 


\subsection{Red chili yield}

Production determines the success of the plant cultivation process. Yield components that support high production are the number of fruit and fruit size. The highest number of fruit produced from the treatment of $10 \mathrm{~g} \mathrm{plant}^{-1}+15 \mathrm{ml} \mathrm{l}^{-1}$ namely 131 , while control only produced 80 fruits. The best fruit size in the parameters of fruit diameter and fruit length in $10 \mathrm{~g} \mathrm{plant}^{-1}+15 \mathrm{ml} \mathrm{l}^{-1}$ treatment was $0.803 \mathrm{~cm}$ and $13.1 \mathrm{~cm}$, respectively. The availability of $\mathrm{N}$, $\mathrm{P}$, and $\mathrm{K}$ elements in liquid organic fertilizers supports the size quality of chilies. This is the following research [16], the available $\mathrm{P}$ and $\mathrm{K}$ elements will help ripen fruit and improve the fruit quality in terms of fruit diameter.

Table 2. The average of yield variables in red chili

\begin{tabular}{|c|c|c|c|c|}
\hline Treatments & $\begin{array}{l}\text { Fruit } \\
\text { length } \\
(\mathrm{cm})\end{array}$ & $\begin{array}{c}\text { Fruit } \\
\text { diameter } \\
(\mathrm{cm})\end{array}$ & $\begin{array}{l}\text { Number of } \\
\text { fruit per } \\
\text { plant }\end{array}$ & $\begin{array}{l}\text { Productivity } \\
\left(\mathrm{t}^{\text {ha-1) }}\right)\end{array}$ \\
\hline $0 \mathrm{~g} \mathrm{plant}^{-1}+0 \mathrm{ml} \mathrm{l}^{-1}$ & $12.2 \mathrm{gh}$ & $0.737 \mathrm{f}$ & $80 \mathrm{j}$ & $7.40 \mathrm{f}$ \\
\hline 0 g plant $^{-1}+5 \mathrm{ml} \mathrm{l}^{-1}$ & $12.0 \mathrm{~h}$ & $0.747 \mathrm{e}$ & $83 \mathrm{ij}$ & $7.87 \mathrm{e}$ \\
\hline $0 \mathrm{~g}_{\text {plant }}{ }^{-1}+10 \mathrm{ml} \mathrm{l}^{-1}$ & $12.2 \mathrm{fg}$ & $0.758 \mathrm{~d}$ & $86 \mathrm{hi}$ & $7.96 \mathrm{e}$ \\
\hline $0 \mathrm{~g} \mathrm{plant}^{-1}+15 \mathrm{ml} \mathrm{l}^{-1}$ & $12.5 \mathrm{e}$ & $0.767 \mathrm{c}$ & $89 \mathrm{~h}$ & $7.98 \mathrm{e}$ \\
\hline 5 g plant $^{-1}+0 \mathrm{ml} \mathrm{l}^{-1}$ & $12.4 \mathrm{ef}$ & $0.767 \mathrm{c}$ & $90 \mathrm{~h}$ & $8.02 \mathrm{e}$ \\
\hline 5 g plant $^{-1}+5 \mathrm{ml} \mathrm{l}^{-1}$ & $12.7 \mathrm{~d}$ & $0.770 \mathrm{c}$ & $95 \mathrm{~g}$ & $8.71 \mathrm{~cd}$ \\
\hline 5 g plant $^{-1}+10 \mathrm{ml} \mathrm{l}^{-1}$ & $12.7 \mathrm{~cd}$ & $0.775 \mathrm{c}$ & $101 \mathrm{f}$ & $8.92 \mathrm{~cd}$ \\
\hline 5 g plant $^{-1}+15 \mathrm{ml} \mathrm{l}^{-1}$ & $12.9 \mathrm{bcd}$ & $0.785 \mathrm{~b}$ & $107 \mathrm{e}$ & $8.93 \mathrm{~cd}$ \\
\hline $10 \mathrm{~g} \mathrm{plant}^{-1}+0 \mathrm{ml} \mathrm{l}^{-1}$ & $12.9 \mathrm{bc}$ & $0.783 \mathrm{~b}$ & $112 \mathrm{~d}$ & $8.49 \mathrm{~d}$ \\
\hline $10 \mathrm{~g} \mathrm{plant}^{-1}+5 \mathrm{ml} \mathrm{l}^{-1}$ & $12.8 \mathrm{bcd}$ & $0.788 \mathrm{~b}$ & $119 \mathrm{c}$ & $9.08 \mathrm{c}$ \\
\hline $10 \mathrm{~g} \mathrm{plant}^{-1}+10 \mathrm{ml} \mathrm{l}^{-1}$ & $13.0 \mathrm{ab}$ & $0.785 \mathrm{~b}$ & $124 \mathrm{~b}$ & $9.62 \mathrm{~b}$ \\
\hline 10 g plant $^{-1}+15 \mathrm{ml} \mathrm{l}^{-1}$ & $13.1 \mathrm{a}$ & $0.803 \mathrm{a}$ & $131 \mathrm{a}$ & $11.16 \mathrm{a}$ \\
\hline $\mathrm{CV}(\%)$ & 0.85 & 0.61 & 2.4 & 2.94 \\
\hline F Value & $2.67 *$ & $2.62 * *$ & $2.66^{*}$ & $13.15^{*}$ \\
\hline
\end{tabular}

Note: The same letter in the same column is not significantly different based on the DMRT test $\alpha$ : $5 \%$, *: significant, **: very significant effect, ns: no significant effect, CV: coefficient of variance.

The highest productivity resulted in the treatment of $10 \mathrm{~g}$ plant $^{-1}+15 \mathrm{ml} \mathrm{l}^{-1}$ is $11.16 \mathrm{t}$ $\mathrm{ha}^{-1}$. The productivity produced in control was $7.40 \mathrm{tha}^{-1}$, the lowest productivity compared to other treatments. This proves that the interaction of mycorrhizal treatment and LOF increases the productivity of red chilies. LOF is a provider of elements and AMF increases the absorption area. This follows with research Dhumal and Shinde [17] that the main determining factor for AMF population and root colonization is the availability of $\mathrm{P}, \mathrm{K}$, and $\mathrm{Na}$ elements to optimize the fruit formation process. In addition, the availability of the element $\mathrm{P}$ is very important, namely stimulating root growth, accelerating flowering, accelerating fruit ripening, and helping the photosynthesis process [18]. 


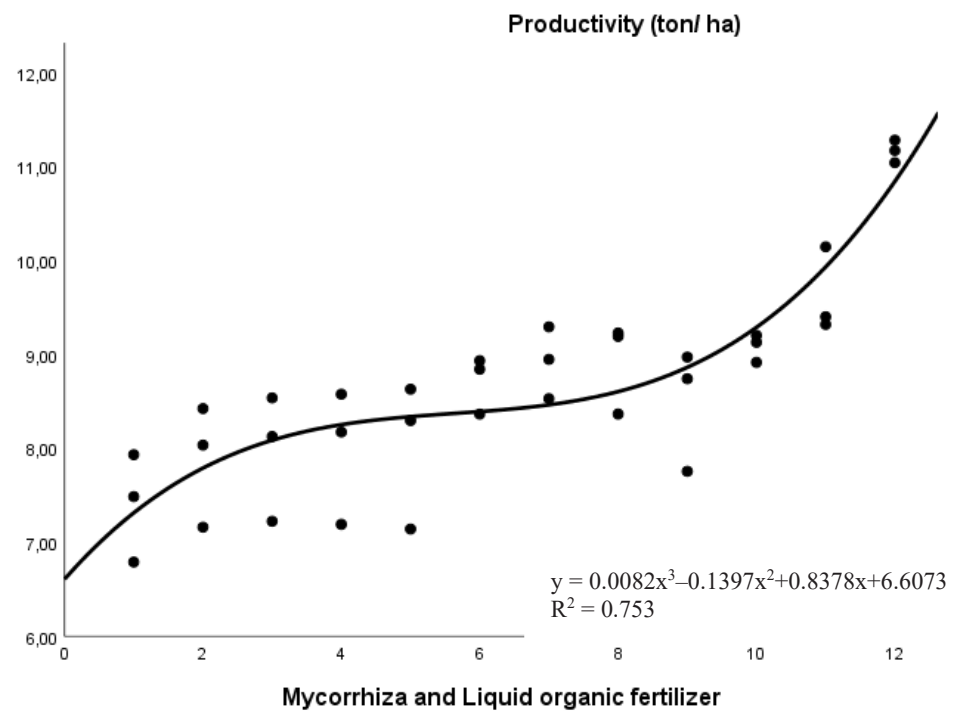

Fig. 1. Productivity of red chilies

Interaction of mycorrhizal inoculation and LOF increased the productivity of red chilies with the highest yield of $11.28 \mathrm{t} \mathrm{ha}^{-1}$. The distribution of productivity data produced in different treatment combinations is depicted in the cubic curve and the $\mathrm{R}$ square value is 0.75 . The diversity of interactions between mycorrhizal and LOF affects the productivity of red chilies by $75 \%$. The other $25 \%$ is influenced by other factors that are not included in the model.

\subsection{Correlation analysis}

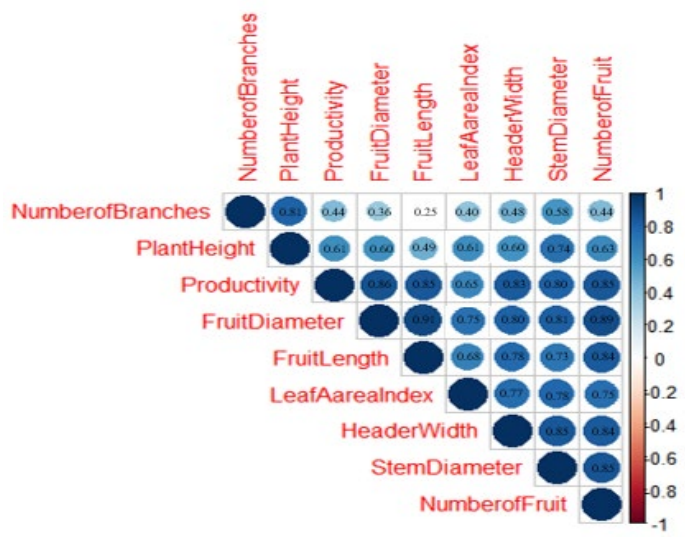

Fig. 2. Correlation analysis between variables in the red chili experiment

The relationship between variables in red chili plants is shown in the correlation analysis in the image above. Based on the figure (Fig. 2.), all variables are positively correlated, shown in blue. However, there is an insignificant correlation between the variables of the number of branches and the length of the fruit with a value of $0.25^{\mathrm{ns}}$, which is shown to be close to white. According to Gomez and Gomez [19], the closer the correlation coefficient to -1 or 1 , the stronger the relationship between these characters. Productivity variables had a 
significant and strong correlation with the variables of the number of fruit, stem diameter, crown width, leaf area index, fruit length, fruit diameter, plant height, and the number of branches, respectively $0.85^{*}, 0.80^{*}, 0.83^{*}, 0.65^{*}, 0.85^{*}, 0.86^{*}, 0.61^{*}, 0.44^{*}$. This means that the greater the number of fruit, stem diameter, header width, leaf area index, fruit length, fruit diameter, plant height, and the number of branches, the more productivity will increase.

\section{Conclusions}

From this finding we conclude that mycorrhizal inoculation and application of liquid organic fertilizers increased the growth and yield component of red chilies. Application of $10 \mathrm{~g}_{\text {plant }}{ }^{-1}$ mycorrhizal inoculation and $15 \mathrm{ml} \mathrm{l}^{-1}$ LOF resulted the optimal growth and the highest yield of red chili.

\section{References}

1. C.K. Koassi, Nevry, L.Y. Guilaume, Z.N. Yasse, M. Koussemon, T. Kablan, K. Kouassi, I. R. F. Biotech. 11 (2012)

2. CBS, Directorate General of Horticulture, www.pertanian.go.id

3. S. Safrianto, Syafruddin, R. Sriwati, J. Floratek 10, 2 (2015)

4. N. Murniati, E. Safriyani, J. J. Agro Silampari. 2 (2012)

5. Makmur, Magfirah, J. G. Tropika. 7, 1 (2018)

6. N.W. Osorio, M. Habte, Arbuscular mycorrhizas: producing and applying (College of tropical agriculture \& Human resources, Hawaii, 2001)

7. M. Prafithriasari, A. Nurbaity, J.A. 21, 1 (2010)

8. Y. Sanchez-roque, L.Y. Perez, J. Bioscience. 4 (2015)

9. H.C. Lakshman, M.G. Nadagouda, Int. J. Agri. Sci. 6, 1 (2010)

10. D.W. Purnomo, The effectiveness of arbuscular fungi in increasing yield and adaptation of chilies (Postgraduate School IPB University, Bogor, 2008)

11. D.H. Pangaribuan, Y.C. Ginting, L.P. Saputra, H. Fitri, J. Hort. Indonesia. 8, 1 (2017)

12. D.M. Orcutt, E.T. Nilsen, The Physiology of plants under stress: Soil and biotic factors (New York: John Wiley, Sons, Inc, 2001)

13. N. Marliana, E. J. 3, 2 (2010)

14. F.B. Salisbury, C.W. Ross, Plant physiology (ITB, Bandung, 1995)

15. M. Wijayanti, M. S. Hadi, E. Pramono, J. A. Tropika. 1, 2 (2013)

16. F.P. Gardner, R.B. Pearce, R.L. Mitchell, Cultivated Plant Physiology (Library of Riau University, Pekanbaru, 2001)

17. K.C. Dhumal, B.P. Shinde, J. Appl. Bio. Biotech. 8, 5 (2020)

18. Lingga, Marsono, Instructions for the use of fertilizers (Self-Help Spreader, Jakarta, 2001)

19. K.A. Gomez, A.A. Gomez, Statistical procedures for agricultural research (UI Press, Jakarta, 1995) 